\title{
On the Nesting of Snowbirds: A Question About Seasonal and Permanent Migrants
}

\author{
Charles F. Longino, Jr. \\ University of Miami \\ Victor W. Marshall \\ University of Toronto \\ Larry C. Mullins \\ University of South Florida \\ Richard D. Tucker \\ University of Central Florida
}

This essay asserts that seasonal and permanent migration may be connected, although there is no direct evidence for this relationship in the current research literature. We draw circumstantial and incomplete evidence for this proposition from findings of a recent survey of Canadian snowbirds in Florida and a parallel study of Canadian-Americans using the 1980 census public use sample migrant file. Other researchers are encouraged to settle the issue by including appropriate items in surveys of snowbirds that would determine whether or not some of the permanent migrants from the same origin serve as an unofficial reception committee for winter visitors, providing for them a socially receptive place to "nest" for the season.

There may be an important relationship between permanent migration and seasonal migration that helps to explain the social integration of older seasonal migrants. Permanent migrants from the same origin may provide for seasonal migrants a socially receptive place to "nest" for the winter. Our purpose is to raise and explore this issue in the hope that it will be added to the agenda of migration researchers in the field of aging, especially those

AUTHORS'NOTE: An earlier version of this article was presented at the annual meeting of the Gerontological Society of America, Washington, DC, November, 1987. Thanks are due to Patty LeBlanc, Frances Cutler, Dawn Leeds, and Ralph McNeal, Jr., for their help with this article, and to the Canadian Embassy, the International Exchange Center on Aging, and the Social Sciences and Humanities Research Council of Canada for the funding they provided.

The Joumal of Applied Gerontology, Vol. 10 No. 2, June 1991 157-168

(C) 1991 The Southern Gerontological Society 
primarily concerned with seasonal migration. At this time, no data have been collected, analyzed, or reported that can directly connect these two types of mobility, although research findings offer some indirect and partial evidence suggesting that such a relationship is possible. The question of a potential connection between seasonal and permanent migration is important theoretically because it goes to the very heart of the definition of migration, and in addition it may offer an insight into the decision process that generates the move.

Vacationing is nonpermanent by nature. It is the most transient of mobility types. Migration theory, however, treats permanence as though it is a binary concept. Migrants make a permanent move, and nonmigrants do not. In reality, permanence is not binary but a gradient concept that forms a continuum. Permanent migrants anchor the continuum on one end, vacationers on the other. The migrants who settle for half a year form the middle ground of the continuum. They stay longer than do vacationers, but they are not permanent.

Permanence is a difficult dimension of migration to study. The census assumes that one's "usual place of residence" is not temporary, migrant farm workers notwithstanding. Persons who moved across major political boundaries in the 5 years before the decade census are considered "permanent" migrants by demographers, no questions asked. Counterstream migration patterns suggest that some permanent migrants may at a later time move back to the state from which they came, rendering them less than permanent in an absolute sense (Litwak \& Longino, 1987). There is also the unresolved research question about the transformation of seasonal migrants into permanent migrants, if they choose to live indefinitely at their seasonal destination.

\section{Gerontology's Contribution to Migration Research}

One of gerontology's major contributions to migration research may be to increase theoretical understanding of permanence as a feature of migration. In reality, much of the migration among older people may be temporary (Cuba, 1988). Krout (1983) found that 14\% of older Upstate New York residents in his survey had spent part of the previous year wintering in another state, usually a Sunbelt state. Estimates of the average length of stay, also derived from various surveys, range from 6.7 months in Florida trailer parks (Hoyt, 1954) to 4.7 months in the Lower Rio Grande Valley of Texas (Rush, 1980).

The only national data on nonpermanent residents are found in a special report on the subject by the U.S. Bureau of the Census (1982). On April 1, 
1980 , the census counted nearly half a million nonpermanent residents, approximately half of whom were in Florida. Not all of them were elderly because seasonal farm workers and construction workers were also counted; and the census missed those who returned home before April 1. The stream to Florida, however, had a high median age (Gober \& Mings, 1984).

Northcott (1988) estimated that seasonal migration among older Canadians is more common than interprovincial moves. This appraisal is supported by Statistics Canada (1984) and Florida Department of Commerce (1982) estimates, which put the number of older Canadian seasonal migrants in Florida alone at a quarter million (Tucker, Marshall, Longino, \& Mullins, 1988).

A number of studies have begun to define seasonal migration as a research area within social gerontology (Hogan, 1987). Seasonal residents, often referred to as "snowbirds" by residents of the Sunbelt states to which they migrate each winter, have been studied almost entirely through local surveys. Research at this point, therefore, comes from a collection of "case studies" using local surveys.

Hogan (1987) pointed out that Arizona seasonal migration, like that of older, permanent migration to the Sunbelt states, may be characterized as relatively advantaged. That is, most migrants are married; retired; generally have high retirement incomes, more education, and better health than the nonmover segment of the elderly population; and are overwhelmingly Anglo (Happel, Hogan, \& Sullivan, 1983, 1984; Monahan \& Greene, 1982; Sullivan, 1985; Sullivan \& Stevens, 1982). Martin, Hoppe, Larson, and Leon (1987) found the same differentials among snowbirds in the Rio Grande Valley of Texas. Climate, visiting with family and friends, recreational opportunities, and lower cost of living attract these visitors. Some also come for health reasons. Krout (1983) noted essentially the same list of attractions when he surveyed returning snowbirds in New York, most of whom had wintered in Sunbelt states. In short, life-style reasons clearly define the motivational field.

Some seasonal migrants in the United States come from other countries. The first large-scale study of international seasonal migrants, a mail questionnaire study of 2,728 older Anglophone Canadians, took place in Florida during 1987 (Tucker et al., 1988). They were predominantly married, healthy, and middle- to upper-middle class. Previous vacationing before buying a residence was common, and many had a long history of progressively more lengthy visits to Florida. Visits lasted about 5 months because Canadians lose their medicare benefits if they spend more than 6 months out of the country each year (Marshall, Longino, Tucker, \& Mullins, 1989). As a result, older Canadians usually do not become permanent international migrants to the 
United States. Naturalization as U.S. citizens is far more common among young people of college or working age (Longino, 1988a). The high rate of home ownership and the geographic stability of their Florida destination foster integration into snowbird communities. Rarely was loneliness a problem (Mullins, Longino, Marshall, \& Tucker, 1989).

\section{How do Migrants Decide Where to Move?}

Before suggesting a theoretical connection between permanent residents and older seasonal migrants, our attention must turn to the broader question of how people decide to move in the first place. The answer is situated in the interaction of three selection processes: self-selection, selective recruitment, and network recruitment.

\section{Self-Selection}

Just wanting to move is no guarantee that the move will take place. It may be too costly or too risky or the idea may not be congenial to all household members (Wiseman, 1980). To complicate things further, each community has its own special attractions and its own built-in inhibitors which, taken together, will tend to attract certain kinds of residents (Lee, 1966). Selfselection processes work for permanent and seasonal migrants (Krout, 1983; Sullivan \& Stevens, 1982). It is easy to speculate about the dynamics of this process for seasonal migrants. Those below certain health and income thresholds cannot easily make the trip, and they tend not to do so.

\section{Selective Recruitment}

In addition to the individual who makes the decision to move, the selective recruitment efforts of the community itself help to match migrants to environments. Consider the selective recruitment by planned retirement communities "for adults only." There are places in Florida to which thousands of winter visitors come. During the winter, these communities increasingly display one of the linguistic Canadian cultures and seem, to natives, to become almost transformed into Canadian villages. Some are advertised heavily in particular Canadian locations and continually recruit new residents from there. The French and English languages also tend to segregate Canadians into different communities. That is, Francophone snowbirds tend to seek out those Florida communities where Francophone Canadians congre- 
gate (the majority are on the Atlantic coast), and Anglophone Canadians seek out Anglophones (mostly on the Gulf coast). In this sense, selective recruitment generates and reinforces self-selection and network recruitment.

\section{Network Recruitment}

In addition to official recruiters, friends and family members make up a corps of informal recruiters in retirement settlements. There is a common pattern for retirement migration. A visiting routine is established with other retired family members and friends, especially if the migrants live near a resort. Visits often prelude a move to the area (even a seasonal move), after which the chain of visits begins anew with a new host. Network recruitment may also be seen from the perspective of the prospective mover who takes the initiative in visiting distant relatives and friends. It may well be the migrant himself or herself who chooses a destination to which relatives and friends have already gone.

Over half of the older migrants who had moved to several Ozark communities in southern Missouri during the mid-1970s knew someone there before they moved (Longino, 1981, 1986). Indeed, they knew an average of five people beforehand, characterized as friends more often than as family members. Nearly all migrants had visited the area at least twice before moving there, and some had vacationed there regularly for many years. Network recruitment, like selective recruitment, is part of a filtering process that results in a general similarity of migrant backgrounds in each community. Network recruitment, however, has a greater long-term impact because it initiates and then maintains the migration streams over time from one place to another.

\section{Do Permanent Migrants Attract Snowbirds From the Same Origins?}

Social gerontologists in the past decade (Longino, 1990) have studied seasonal and permanent migration, although the two types of mobility have not been linked. Even in the absence of focused research on this topic, however, there are findings in the literature that may provide an indirect empirical basis for speculations that other researchers may test in the future. What would constitute minimal evidence for the influence of permanent migration on seasonal migration? Migrants of both types from the same origin would have to have settled in the same destination. Only then could 
the potential exist for a type of network recruitment in which permanent residents encourage seasonal migration. This level of evidence would be necessary but not sufficient to demonstrate such a proposition.

Such minimal evidence is available in two parts of a study of Canadian snowbirds in Florida: the survey of snowbirds and a census analysis of permanent residents. Marshall and Longino (1988) found in the survey data some indirect evidence of network recruitment: Of older Anglophone Canadian snowbirds in Florida, 2\% had one or more children who lived permanently in Florida, within 50 miles of their parents' wintering home. This seems like an unimportant matter, but the story continues: Eight percent reported that at least one of their siblings was a permanent resident of Florida and lived closer than 50 miles. Finally, $\mathbf{8 \%}$ said they had another relative, other than children and siblings, who lived nearby and permanently in Florida. Depending on the degree of overlap between these categories, from 8 to $18 \%$ of the Canadian snowbirds had family members living permanently in Florida - close enough to be an important part of their social environment. The contact with permanently resident family members by seasonal migrants is certainly a suggestive finding. Another is that $70 \%$ of the retired snowbirds from Canada had friends who were permanent residents of Florida (Marshall \& Longino, 1988). Half of them had 6 or more friends, and nearly a fifth had 11 or more.

Many Canadian snowbirds say that they have family members or friends who live year-round in Florida. Is there any evidence from other data sources that such Canadian permanent migrants do reside in Florida? If so, some of these Canadian permanent migrants may have served as an unofficial reception committee and been an important part of the social networks of Canadian winter visitors. To examine this second piece of the puzzle, Longino (1988a) extracted from the 1-in- 40 census microdata migrant file the records of all persons born in Canada who, in 1980, were permanent residents of the United States (Longino, 1982; Longino \& Teicher, 1982; U.S. Bureau of the Census, 1983).

In 1980 fewer than a million $(833,920)$ native-born Canadians lived in the United States. Most (84.4\%) of these migrants had become naturalized U.S. citizens; $39 \%$ were 60 or older. Florida is the only distant state from the Canadian border on the East Coast that attracts native-born Canadians in large numbers. In 1980 there were 70,540 persons of all ages living in Florida who had been born in Canada. Furthermore, the researchers found that Florida is even more attractive to persons born in Canada who are in their 60 s or older; nearly half of the native-born Canadians who live in Florida are in that age group. On April 1, 1980, there were 34,700 of them in Florida. 


\section{Discussion}

The survey of older Anglophone Canadian seasonal migrants does not "prove" that permanent Canadian-born migrants to Florida function to recruit snowbirds or to make them more comfortable once they come. Unfortunately, no direct questions were asked in the interview that would firmly establish this point. A minority of them are in contact with family members who live year-round in Florida. One might assume that these persons had migrated permanently. A much larger part of the Canadian snowbirds have friends among year-round Florida residents. If many of these friends were Canadian by birth then the research proposition would be supported. One could speculate that many of the Florida friends that Canadian winter visitors mentioned are also Canadians, considering that Florida has over 70,000 permanent residents who were born in Canada, and that a high proportion of them live in mobile homes and condominiums (Longino, 1988a), the favored type of residence for seasonal migrants (Tucker at al., 1988). Nevertheless, this evidence is only circumstantial. Direct evidence from another survey would be necessary to turn this speculation into a finding.

\section{Place Ties at Destination}

We do not mean to imply in this essay that no research has examined the "unofficial reception committee" phenomenon in other contexts. There has been considerable research by demographers (DeVanzo \& Morrison, 1982; Goldscheider, 1971; Price \& Sykes, 1975) on place ties. Furthermore, the impact of place ties on elderly permanent migration has been observed, at origin and destination (Gober \& Zonn, 1983; Oldakowski \& Roseman, 1986; Roseman \& McHugh, 1982; Roseman \& Williams, 1980).

Among these findings DeVanzo and Morrison (1982) noted that attachment at destination is a key factor in those who return to their states of birth. Roseman and Williams (1980) found that migration to nonmetropolitan areas is typically preceded by vacation ties to that area. Researchers have also noted that friends and relatives at the destination place are important in attracting new migrants in rural-to-urban and international migration streams (Goldscheider, 1971; Price \& Sykes, 1975). These same processes have been observed among elderly migrants selecting retirement communities (Cuba, 1988; Gober \& Zonn, 1983). Furthermore, Oldakowski and Roseman (1986) showed in their research that working persons consider place ties at origin more important; as workers approach retirement there seems to be a shift in 
influence from origin toward place ties at potential destination as a result of intensification of contacts with other areas.

Whether or not these same processes take place among seasonal migrants, however, is still unclear. McHugh (1990) examined three studies that asked seasonal migrants whether or not they were considering making a permanent move. These studies found that between $21 \%$ and $30 \%$ were considering making their move permanent. He then concluded that seasonal visits serve as a prelude to permanent migration for only a limited number of seasonal migrants. When considering Canadians, this stricture would be even more severe. McHugh concludes that seasonal migration is a life-style rather than a prelude to permanent migration.

If this is so, then more detailed study is necessary to determine what distinguishes seasonal and permanent migrants, and national and international seasonal migrants among them, and the processes whereby they decide to move and where to move. However, if one assumes that motivation to move might develop because of satisfactory seasonal-migration experiences, then the percentage to eventually develop such motivation would be higher. Seasonal migrants have a large impact on the political, social, and economic landscapes at their places of origin and destination. Therefore, studies need to be undertaken to determine the demographics of these people, as well as the selection processes they employ. We are speculating in this essay that the location of permanent international migrants in large numbers, especially those who have grown to retirement age, may be an important key to understanding the place ties at destination for seasonal migrants from the same countries. With only the partial data that were available, we examined the case of Canadian snowbirds in Florida.

\section{A Policy Issue}

The policy issue underlying the concern about migration selection processes and recruitment is that migration may have a negative impact on the use of scarce health and social resources. The fear that older migrants place a service burden on the receiving community has been referred to as the "gray peril mentality" by several students of migration impact (Longino, 1988b; Rosenbaum \& Button, 1989). Would any research evidence justify this fear?

Rosenbaum and Button (1989) found that older Floridians tended to be politically active but were seldom involved in organized advocacy for their own interests or in political opposition to local policies that are largely beneficial to other interests. Longino and Crown (1989) further established that older migrants into the major Sunbelt receiving states bring large 
amounts of income with them, an economic development bonanza for less populated counties with sizable migrant inflows. In 1990, Florida alone received $\$ 6$ billion of before-tax annual income just from its older migrants in projected 1990 dollars.

Some dub retirement migration as the growth industry of the 1990s in small-town America (Summers \& Hirschl, 1985) because it increases economic consumption and broadens the tax base. When rural counties float on a cushion of social security, pensions, annuities and asset income, economic conditions locally improve, particularly in the service sector (Glasgow, 1988).

Retired migrants may have a negative impact on local health care by overburdening the delivery system or by redirecting its focus on the old to the neglect of others. Haas and Crandall (1988) addressed this issue in two rural counties affected by elderly migration, one in Florida and the other in North Carolina. They found that the great increase in Medicare patients in these rural counties stimulated the health care economy and attracted a number of new physicians so that everyone, young and old alike, benefited. Increased use of health services by older migrants was not a local burden because their medical care was largely paid for by Medicare transfers from Washington.

Tucker et al. (1988) found that English-speaking Canadian snowbirds place a minimal demand on health care and social services in Florida while spending a reported $\$ 1,200$ per month in U.S. dollars during their average five-month stay. In addition to their direct economic contribution, their very presence attracts tourism visits from children and other relatives, generating direct and multiplier effects on the economy of the communities where the seasonal migrants reside (Longino \& Crown, 1989).

The minimal demand that Canadian visitors make on the local health care system results from their access annually to two different health care systems. Before leaving Canada, $84 \%$ of them visit a Canadian doctor for a check-up, or as several put it, "a major tune-up." Most stock up on prescription drugs. One third leave specific instructions with relatives or friends in case of a possible medical emergency. Fully $81 \%$ enroll in a private health insurance plan to supplement their provincial health plan (Marshall et al., 1989).

Fewer than $1 \%$ report a need for assistance with any activities of daily living. Given the high level of independence found in this sample of Canadian snowbirds, and the typical availability of a spouse, it is not surprising that almost none of them use Florida social services for the elderly, such as senior centers, special transportation, meal delivery or congregate meal sites, homemaker services, visiting nurses, home health aids, or adult day care. Senior 
centers were most often listed, but by fewer than $2 \%$ of the respondents. All other items combined were listed by fewer than $4 \%$ of the sample. The search for local public service impact on specialized services for the aged by seasonal migrants has turned up disappointingly little evidence for the gray peril (Tucker et al., 1988).

If older migrants, and particularly winter visitors, have a net positive impact on the local community, how can local planners encourage their arrival and nurture their nesting? Studies of retirement migration, and particularly the selection processes underlying it, are a benefit to community planners who understand the advantage to be derived from making room for older in-migrants. That is why we need more studies of these processes, including the relationship between permanent and seasonal migrants.

\section{References}

Cuba, L. J. (1988, November). From visitor to resident: Retiring to vacationland. Paper presented at the annual meeting of the Gerontological Society of America, San Francisco.

DeVanzo, J., \& Morrison, P. (1982). Migration sequences: Who moves back and who moves on (R-2548). Santa Monica, CA: RAND.

Florida Department of Commerce. (1982). Canadian travel patterns and attitudes towards vacations in Florida. Tallahassee: Florida Department of Commerce, Division of Tourism.

Glagow, N. (1988). The nonmetro elderly: Economic and demographic status (RDRR-70). Washington, DC: U.S. Department of Agriculture, Economic Research.

Gober, P. C., \& Mings, R. C. (1984). A geography of nonpermanent residence in the United States. Professional Geographer, 36, 292-296.

Gober, P. C., \& Zonn, L. E. (1983). Kin and elderly amenity migration. Gerontologist, 23, 288-294.

Goldscheider, C. (1971). Population, modernization and social structure. Boston: Little, Brown.

Haas, W. H., \& Crandall, L. A. (1988). Physicians' view of retirement migrants' impact on rural medical practice. Gerontologist, 28, 663-666.

Happel, S. K., Hogan, T. D., \& Sullivan, D. (1983). The social and economic impact of Phoenix area winter residents. Arizona Business, 30, 3-10.

Happel, S. K., Hogan, T. D., \& Sullivan, D. (1984). Going away to roost. American Demographics, 6, 33-35, 44-45.

Hogan, T. D. (1987). Determinants of the seasonal migration of the elderly to Sunbelt states. Research on Aging, 9, 115-133.

Hoyt, G. C. (1954). The life of the retired in a trailer park. American Journal of Sociology, 19, 361-370.

Krout, J. A. (1983). Seasonal migration of the elderly. Gerontologist, 23, 295-299.

Lee, E. (1966). A theory of migration. Demography, 3, $47-57$.

Litwak, E., \& Longino, C. F., Jr. (1987). Migration patterns among the elderly: Adevelopmental perspective. Gerontologist, 27, 266-272.

Longino, C. F., Jr. (1981). Where to retire to. Chemtech, 11, 524-526. 
Longino, C. F., Jr. (1982). Applied gerontology and the 1980 census. Journal of Applied Gerontology, 1, 19-25.

Longino, C. F., Jr. (1986). Personal determinants and consequences of independent housing choices. In R. J. Newcomer \& M. P. Lawton (Eds.), Housing an aging society (pp. 83-93). New York: Van Nostrand Reinhold.

Longino, C. F., Jr. (1988a). Canadian-born residence in the United States. In L. C. Mullins \& R. D. Tucker (Eds.), Snowbirds in the Sun Belt: Older Canadians in Florida (pp. 17-36). Tampa: University of South Florida, International Exchange Center on Gerontology.

Longino, C. F., Jr. (1988b). The gray peril mentality and the impact of retirement migration. Journal of Applied Gerontology, 7, 448-455.

Longino, C. F., Jr. (1990). Geographical distribution and migration. In R. H. Binstock \& L. K. George (Eds.), Handbook of aging and the social sciences, 3rd ed. (pp. 45-63). San Diego, CA: Academic Press.

Longino, C. F. Jr., \& Crown, W. H. (1989). The migration of old money. American Demographics, $11,28-31$.

Longino, C. F., Jr., \& Teicher, M. I. (1982). An introduction to the 1980 census. In C. C. Osterbin, W. Mangum, \& M. I. Teicher (Eds.), Data based planning in the field of aging (pp. 75-84). Gainesville: University Presses of Florida.

Marshall, V. W., \& Longino, C. F., Jr. (1988). Older Canadians in Florida: The social networks of international seasonal migrants. Comprehensive Gerontology, 2, 63-68.

Marshall, V., Longino, C. F., Jr., Tucker, R., \& Mullins, L. G. (1989). Health care utilization of Canadian snowbirds: An example of strategic planning. Journal of Aging and Health, 1, 150-168.

Martin, H. W., Hoppe, S. K., Larson, C. L., \& Leon, R. L. (1987). Texas snowbirds: Seasonal migrants to the Rio Grande Valley. Research on Aging, 9, 134-147.

McHugh, K. E. (1990). Seasonal migration as a substitute for or precursor to, permanent migration. Research on Aging, 12, 229-245.

Monahan, D. J., \& Greene, V. L. (1982). The impact of seasonal population fluctuations on service delivery. Gerontologist, 22, 160-163.

Mullins, L. G., Longino, C. F., Jr., Marshall, V., \& Tucker, R. (1989). An examination of loneliness and social isolation among elderly Canadian seasonal migrants in Florida.Journal of Gerontology: Social Sciences, 44, 580-586.

Northcott, H. C. (1988). Changing residence: The geographic mobility of elderly Canadians. Toronto: Butterworths.

Oldakowski, R. K., \& Roseman, C. C. (1986). The development of migration expectations: Changes throughout the lifecourse. Journal of Gerontology, 41, 290-295.

Price, D., \& Sykes, M. (1975). Rural-urban migration research in the United States. Bethesda, MD: National Institute on Child Health and Human Development, Center for Population Research.

Roseman, C. C., \& McHugh, K. E. (1982). Metropolitan areas as redistributors of population. Urban Geography, 3, 22-23.

Roseman, C. C., \& Williams, J. D. (1980). Metropolitan and nonmetropolitan migrations; A decision-making perspective. Urban Geography, 1, 283-294.

Rosenbaum, W. A., \& Buttons, J. W. (1989). Is there a gray peril?: Retirement politics in Florida. Gerontologist, 29, 300-306.

Rush, C. H. (1980). Winter Texans in the Lower Rio Grande Valley. Texas Business Review, 54, 171-175. 
Statistics Canada. (1984). Canadian travel to the United States. Ottawa: Statistics Canada, International Travel Section.

Sullivan, D. A. (1985). The ties that bind: Differentiais between seasonal and permanent migrants to retirement communities. Research on Aging, 7, 235-50.

Sullivan, D. A., \& Stevens, S. A. (1982). Snowbirds: Seasonal migrants to the Sunbelt. Research on Aging, 4, 159-177.

Summers, G. F., \& Hirschl, T. A. (1985). Retirees as a growth industry. Rural Development Perspectives, 12, 13-16.

Tucker, R. D., Marshall, V. W., Longino, C. F., Jr., \& Mullins, L. C. (1988). Older anglophobe Canadian snowbirds in Florida: A descriptive profile. Canadian Journal on Aging, 7, 218-232.

U.S. Bureau of the Census. (1982). Nonpermanent residents by states and selected counties and incorporated places: 1980 (Supplementary Report PC80-S1-6). Washington, DC: Department of Commerce.

U.S. Bureau of the Census. (1983). Census of population and housing, 1980: Public-use microdata samples (Technical Documentation). Washington, DC: Department of Commerce.

Wiseman, R. F. (1980). Why older people move: Theoretical issues. Research on Aging, 2, 141-154.

Charles F. Longino, Jr., is a professor of sociology and the associate director of the Center for Adult Development and Aging at the University of Miami in Coral Gables, Florida. He is the author of the chapter on migration and geographical distribution in the recent edition of the Handbook on Aging and the Social Sciences. His current NIA-funded research focuses on functional disability and geographic mobility.

Victor W. Marshall is the director of the Centre for Studies of Aging at the University of Toronto and the director of the Canadian Aging Research Network, a consortium of researchers and corporations conducting a broad program of research on aging. For the past 5 years, Dr. Marshall has edited the Canadian Journal on Aging. Current research interests are aging and the family, health promotion, and health policy; publications include Aging in Canada: Social Perspectives and Later Life: The Social Psychology of Aging.

Larry C. Mullins is a professor in and the chair of the Department of Gerontology of the University of South Florida, Tampa, where he is also the program coordinator of the International Exchange Center on Gerontology. His major area of interest is comparing the elderly cross-culturally, in all facets. Recent publications include articles on depression and loneliness (Gerontologist, 1990), and loneliness among elderly Canadian seasonal residents (Journal of Gerontology, 1989).

Richard D. Tucker is a professor in and the chair of the Department of Psychology at the University of Central Florida, Orlando. He has been the principal investigator of an ongoing study of older Canadians in Florida since 1986. His current research interest is measures of well-being in both functional and dysfunctional elderly populations. 